\title{
Profile of intoxications served at the 24-hour emergency service unit
}

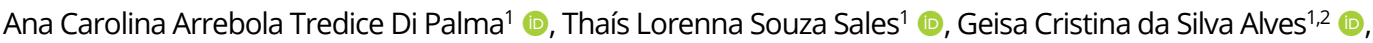 \\ Sayonara Maria Lia Fook ${ }^{3}$ (D), Alba Otoni ${ }^{1}$ (D) , Cristina Sanches ${ }^{1}$ (D), Farah Maria Drumond Chequer ${ }^{1 *}$ (1) \\ ${ }^{1}$ Universidade Federal de São João del-Rei (UFSJ), Divinópolis, MG, Brasil \\ ${ }^{2}$ Universidade de Itaúna, Itaúna, MG, Brasil \\ ${ }^{3}$ Universidade Estadual da Paraíba (UEPB), Departamento de Farmácia, Campina Grande, PB, Brasil \\ *Corresponding author: farahchequer@ufsj.edu.br
}

\begin{abstract}
Intoxications represent a serious public health problem. According to the World Health Organization, 193,000 deaths per year are caused by unintended intoxications worldwide. This study aims to know the profile of intoxications at the 24-hour Emergency Service Unit in Divinópolis, in the state of Minas Gerais. This is a descriptive study in which the study population chosen were all patients treated for intoxications in the period from 2017 to 2018, registered in the health service; 421 cases of intoxications were recorded. The female gender was the most prevalent, and the age group with the most cases was 21 to 30 years. The main circumstance found was attempted suicide $(83.1 \%)$, and the main causative agent was drugs $(76.5 \%)$, with benzodiazepines being the main class responsible for intoxications. The most used treatment was gastric lavage and activated charcoal. This study demonstrates that knowledge about the city's intoxication profile is important for the development of treatment and patient management methods to better suit the demands of the municipality.
\end{abstract}

Keywords: Toxic Substances. Suicide, Attempted. Benzodiazepines. Gastric Lavage.

\section{How to cite}

Di Palma ACAT, Sales TLS, Alves GCS, Fook SML, Otoni A, Sanches C, Chequer FMD. Profile of intoxications served at the 24-hour emergency service unit. Rev Ciênc Farm Básica Apl. 2020;41:e680. https://doi.org/10.4322/2179-443X.0680

\section{INTRODUCTION}

Intoxications are defined as harmful effects arising from the interaction of one or more toxic agents with the biological system, which are capable of triggering an organic imbalance and manifesting clinical and/or laboratory alterations (Brasil, 2018). Intoxication cases are commonly observed in hospital emergencies and represent a serious public health problem. According to the World Health Organization (WHO), 193,000 worldwide deaths per year are caused by unintentional intoxication (World Health Organization, 2018, 2019a). In relation to intentional causes, according to the World Health Organization, this is among the twenty main causes of death worldwide. There are an estimated 800,000 deaths from suicide attempts each year. In most countries, suicide rates are low for the group of children under 15 and increase progressively with age, and existing personal, health, and professional problems become the main focus of suicide attempts (World Health Organization, 2019b). 
In the United States, the report of the American Association of Poison Control Centers, issued by the National Poison Data System (NPDS), shows that 2,099,751 cases of intoxication and 3,111 deaths were recorded in the year 2018, with drugs, household cleaning substances, cosmetics and personal care products being considered as the main intoxicating agents (Gummin et al., 2019). In Brazil, data from the Toxicological Information and Assistance Centers (Centros de Informação e Assistência Toxicológica - CIATOXs), notified on the platform of the Notifiable Diseases Information System (Sistema de Informação de Agravos de Notificação SINAN) registered 135,441 cases of intoxication across the country in 2017. The main classes of substances responsible for intoxication, among a group of 15 chemical substances, are drugs (45.9\%; $n=62,199$ cases), drugs of abuse (13.7\%; $n=18,516)$, pesticides $(12.8 \% ; n=$ $7,412)$, food and beverages $(7.3 \% ; n=9,841)$, household cleaning products $(5.5 \% ; n=7,433)$, and rodenticides $(2.5 \% ; n=5,332)$. Currently, drugs of abuse are noteworthy, demonstrating that notification for this type of injury is of great relevance in our country (Brasil, 2017b).

In the world scenario, the evidence indicates that in cases of intoxication, one of the most common circumstances is attempted suicide, with medication and pesticides being the most used substances for this purpose (Bachmann, 2018). Studies aimed at assessing the intoxication profile in different Brazilian states have shown results similar to world estimates, in which suicide attempt is among the main circumstances of exposure to toxic agents, with drugs being mainly responsible for intoxication (Chaves et al., 2017; Ribeiro et al., 2018; Epifânio et al., 2019).

In this regard, it is known that by knowing the profile of intoxications in a given population, it is possible to identify potential risk conditions to which individuals are exposed, and thus prioritize strategies for handling and resolving cases. In view of the above, the present study has the objective of assessing the profile of intoxications recorded at the Emergency Care Unit (Unidade de Pronto Atendimento - UPA 24h) in Divinópolis - Minas Gerais (MG), this being a municipality in which the absence of a recent data survey is noted regarding the topic.

\section{MATERIAL AND METHODS}

\section{Study design}

This is a study with a quantitative approach and retrospective character, aimed at identifying intoxications registered at the UPA 24h in the municipality of Divinópolis - MG, from January 2017 to December 2018.

The drugs were classified according to the Anatomical Therapeutic Chemical (ATC) classification system, recommended by the World Health Organization, which classifies drugs into different classes, according to their therapeutic and chemical characteristics (Chen et al., 2012).

\section{Study location}

The municipality of Divinópolis is part of the mid-west region of Minas Gerais and is located $134 \mathrm{~km}$ from the state capital. It has an estimated population of 235,977 inhabitants and a Human Development Index (HDI) of 0.764 . It is the main city of the expanded health regions, being responsible for the health demands and availability in the western region of Minas Gerais according to Instituto Brasileiro de Geografia e Estatística (2010). UPA 24h is therefore not limited only to the municipality of Divinópolis-MG, it also meets the demands of the 55 municipalities that are part of the western macro-region.

\section{Study participants}

The population eligible for this study was composed of patients who were admitted to the UPA from January 2017 to December 2018, whose reason for hospitalization was stated in the internal records of the Health Unit and also in the medical records of these same patients as "exogenous intoxication". When these patients were admitted to the UPA, they were first 
screened by nurses. These professionals classified the patient using the Manchester protocol for the risk assessment of patients attended in an emergency. In the present study, were analyzed the medical records of patients in which they were classified as "overdose and poisoning" (number 36) in this Manchester Triage System. These same intoxication cases were reported at SINAN, using investigation form for "exogenous intoxication".

Inclusion criteria: people of both genders, of all age groups admitted to the UPA for "exogenous intoxication", the reason for admission being recorded in medical records and in the internal records of the Health Unit.

Exclusion criteria: people whose reason for admission to the UPA was registered as attempted suicide, in which the causes were not derived from intoxications.

\section{Data collection}

Data collection was carried out by researchers trained for the retrospective evaluation of clinical care reports available in the Integrated Health System (Sistema Integrado de Saúde SIS) of the municipality. The form used as a collection instrument has fields for filling in the following variables: age, gender, city, residential area, toxic agent, circumstance of exposure, and procedure performed. The selection of variables present in the form was based on components of the SINAN intoxication form.

The circumstance of intoxication was categorized into unintentional and intentional intoxication for statistical purposes. The patients included in the group of unintentional intoxication were those whose circumstances of exposure were associated with accidental, food, environmental, and occupational situations, and use and abuse of alcoholic beverages and drugs. The patients included in the intentional intoxication group were those whose circumstances of exposure were associated with criminal situations and suicide attempts.

\section{Data analysis}

The data obtained were entered into the Questionnaire Development System ${ }^{\circledR}$ (QDS) software, and statistical analyzes were performed using the Statistical Package for the Social Science ${ }^{\circledR}$ software (version 19.0). In this study, a descriptive analysis was performed by means of frequency distribution, median and interquartile range. It is noteworthy that for the variable age, the Kolmogorov-Smirnov test was used in order to verify the normality of the data.

\section{Ethical considerations}

The study was approved by the Research Ethics Committee of the Federal University of São João del-Rei, under CAAE 98526718.7.0000.5545 and its conduct was based on resolution 466/2012, which regulates research involving human beings.

\section{RESULTS}

During the study period, 421 cases of intoxication were identified. Regarding sociodemographic characteristics, there was a predominance of females $(67.7 \% ; n=285)$, with $(2.1 \% ; n=6)$ being pregnant. The patients attended were between 1 and 81 years old, the median age of the patients attended was 31 years (IQ25\%: 21 / IQ75\%:42) and the majority were resident in the urban area $(96.2 \% ; n=405)$, mainly in the city of Divinópolis-MG $(95.2 \%$; $\mathrm{n}=$ 401) (Table 1).

As shown in Table 1, the odds ratio results indicated that patients aged 21 to 30 years are 18.883 times more likely to have intentional intoxication compared to patients aged $\geq 60$ years. Regarding gender, female patients are 6.313 times more likely to attempt suicide when compared to male patients; and with regard to the residential area, patients residing in the urban area have 7.393 more times for attempting suicide compared to patients in the rural area. 
Table 1: Univariate analysis of the association between circumstances and sociodemographic characteristics, of patients attended at the Emergency Care Unit (UPA 24h), Divinópolis-MG, Brazil (2017-2018) $(n=421)$

\begin{tabular}{|c|c|c|c|c|c|c|c|c|}
\hline \multirow{2}{*}{ VARIABLES } & \multicolumn{2}{|c|}{ TOTAL } & \multicolumn{2}{|c|}{$\begin{array}{l}\text { UNINTENTIONAL } \\
\text { INTOXICATION } \\
\end{array}$} & \multicolumn{2}{|c|}{$\begin{array}{l}\text { INTENTIONAL } \\
\text { INTOXICATION }\end{array}$} & \multirow{2}{*}{ OR (Cl95\%) } & \multirow{2}{*}{ p-value } \\
\hline & $\mathbf{N}$ & $\%$ & $\mathbf{N}$ & $\%$ & $\mathbf{N}$ & $\%$ & & \\
\hline \multicolumn{9}{|l|}{ Age range } \\
\hline 1 to 10 years & 17 & 4.0 & 17 & 24.6 & 0 & 0.0 & N/A & 0.998 \\
\hline 11 to 20 years & 84 & 20.0 & 10 & 14.5 & 74 & 21.0 & $8.140(2.760-24.003)$ & $0.000 *$ \\
\hline 21 to 30 years & 109 & 25.9 & 6 & 8.7 & 103 & 29.3 & $18.883(5.757-61.936)$ & $0.000 *$ \\
\hline 31 to 40 years & 95 & 22.6 & 11 & 15.9 & 84 & 23.9 & $8.400(2.904-24.300)$ & $0.000 *$ \\
\hline 41 to 50 years & 61 & 14.5 & 8 & 11.6 & 53 & 15.1 & $7.288(2.345-22.651)$ & $0.001 *$ \\
\hline 51 to 59 years & 34 & 8.1 & 6 & 8.7 & 28 & 8.0 & $5.133(1.502-17.547)$ & $0.009 *$ \\
\hline$\geq 60$ years & 21 & 5.0 & 11 & 15.9 & 10 & 2.8 & 1 & \\
\hline \multicolumn{9}{|l|}{ Gender } \\
\hline Male & 136 & 32.3 & 47 & 68.1 & 89 & 25.3 & 1 & \\
\hline Female & 285 & 67.7 & 22 & 31.9 & 263 & 74.7 & $6.313(3.604-11.057)$ & $0.000^{*}$ \\
\hline \multicolumn{9}{|l|}{ Residential zone } \\
\hline Rural & 16 & 3.8 & 9 & 13.0 & 7 & 2.0 & 1 & \\
\hline Urban & 405 & 96.2 & 60 & 87.0 & 345 & 98.0 & $7.393(2.652-20.606)$ & $0.000 *$ \\
\hline
\end{tabular}

N/A: Not applicable; OR: odds ratio; CI: Confidence Interval.

The main circumstances associated with intoxications were suicide attempts $(83.1 \% ; n=350)$, followed by environmental exposure $(8.8 \% ; n=37)$. Among the 421 patients in the study, 352 (83.6\%) had intentional intoxication. Of these patients with intentional intoxication, $99.4 \%(n=350)$ attempted suicide and only $0.6 \%(n=2)$ suffered criminal exposure. Of the 421 patients in the study, 69 (16.4\%) had unintentional poisoning, and the main circumstances of exposure were: environmental exposure; accidental exposure; use and abuse of alcoholic beverages and/or illicit drugs; occupational exposure or food exposure (Table 2).

Table 2. Distribution of the main circumstances of exposure according to the different types of intoxication in patients seen at the Emergency Care Unit (UPA 24h), Divinópolis-MG, Brazil (2017-2018)

\begin{tabular}{|c|c|c|c|}
\hline EXPOSURE CIRCUMSTANCES & $\mathbf{N}$ & $\begin{array}{l}\text { \% in relation to } \\
\text { unintentional intoxications } \\
(n=69)\end{array}$ & $\begin{array}{l}\% \text { in relation to the total } \\
\text { number of study patients } \\
(n=421)\end{array}$ \\
\hline \multicolumn{4}{|l|}{ Unintentional intoxication $(n=69)$} \\
\hline Environmental exposure & 37 & 53.6 & 8.8 \\
\hline Accidental exposure & 19 & 27.5 & 4.5 \\
\hline $\begin{array}{l}\text { Use and abuse of alcoholic beverages and/or } \\
\text { illicit drugs }\end{array}$ & 6 & 8.7 & 1.4 \\
\hline Occupational exposure & 4 & 5.8 & 1.0 \\
\hline \multirow[t]{2}{*}{ Food exposure } & 3 & 4.3 & 0.7 \\
\hline & & $\begin{array}{l}\% \text { in relation to intentional } \\
\text { intoxications }(n=352)\end{array}$ & $\begin{array}{l}\% \text { in relation to the total } \\
\text { number of study patients } \\
\qquad(n=421)\end{array}$ \\
\hline \multicolumn{4}{|l|}{ Intentional intoxication $(\mathrm{n}=352)$} \\
\hline Suicide attempt & 350 & 99.4 & 83.1 \\
\hline Criminal exposure & 2 & 0.6 & 0.5 \\
\hline
\end{tabular}


Regarding suicide attempts, in 2017 there was a large number of cases $(n=182)$, with August being the month with the most recorded. In 2018, 168 cases were observed, with December being the month with the highest frequency (Figure 1). In this scenario it is worth noting that $0.85 \%(n=3)$ of patients with records of attempted suicide died.

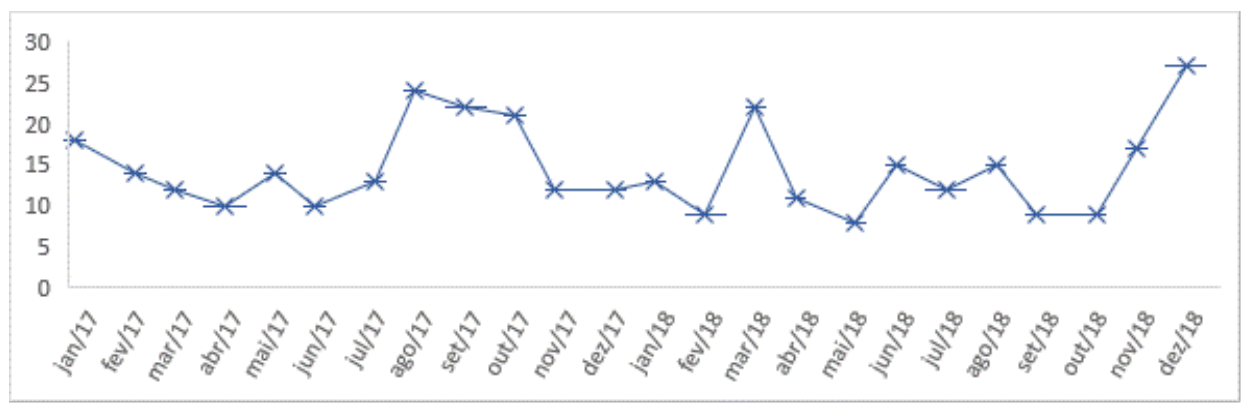

Figure 1. Distribution of the number of cases of suicide attempts, according to seasonal distribution, of patients treated for poisoning at the Emergency Care Unit (UPA 24h), Divinópolis-MG, Brazil (2017-2018)

$$
(n=350) \text {. }
$$

It was observed that for unintentional exposures categorized as environmental, accidents by venomous animals predominated. In this case it was possible to identify snakes $(50.0 \% ; n=18)$, scorpions $(19.4 \% ; n=7)$ and bees $(16.7 \% ; n=6)$ as those mainly responsible for intoxication caused by animals.

In relation to the age group of 1-10 years, the most common circumstance was accidental intoxication, caused mainly by ingestion of drugs (33.3\%) and stings from poisonous animals (33.3\%), followed by ingestion of aldicarb (16.6\%).

Considering the groups of chemical substances studied which are responsible for the cases of intoxications, drugs occupied the first position (76.5\%; $n=322$ ), followed by pesticides (11.9\%; $n=50$ ).

The univariate analysis shows that drugs increase the chance of suicide attempts by 35.060 times $(95 \% \mathrm{Cl} 17.393-70.670)$. The chances of suicide attempts by chemical agents are lower at $0.286(95 \% \mathrm{Cl} 0.107-0.765)$ (Table 3$)$.

Table 3. Univariate analysis of the association between type of intoxication and toxic agents, of patients attended at the Emergency Care Unit (UPA 24h), Divinópolis-MG, Brazil $(2017-2018)(n=421)$

\begin{tabular}{|c|c|c|c|c|c|c|c|c|}
\hline \multirow{2}{*}{ VARIABLES } & \multicolumn{2}{|c|}{ TOTAL } & \multicolumn{2}{|c|}{$\begin{array}{l}\text { UNINTENTIONAL } \\
\text { INTOXICATION }\end{array}$} & \multicolumn{2}{|c|}{$\begin{array}{l}\text { INTENTIONAL } \\
\text { INTOXICATION }\end{array}$} & \multirow{2}{*}{ OR $(95 \% \mathrm{Cl})$} & \multirow{2}{*}{ p-value } \\
\hline & $\mathbf{N}$ & $\%$ & $\mathbf{N}$ & $\%$ & $\mathbf{N}$ & $\%$ & & \\
\hline Drugs & 322 & 76.5 & 12 & 17.4 & 310 & 88.1 & $35.060(17.393-70.670)$ & $0.000 *$ \\
\hline Pesticides & 50 & 11.9 & 4 & 5.8 & 46 & 13.1 & $2.443(0.850-7.024)$ & 0.097 \\
\hline $\begin{array}{l}\text { Venomous } \\
\text { animals }\end{array}$ & 36 & 8.6 & 36 & 52.2 & 0 & 0.0 & N/A & 0.997 \\
\hline $\begin{array}{c}\text { Alcoholic } \\
\text { beverages } \\
\text { and/or illicit } \\
\text { drugs }\end{array}$ & 35 & 8.3 & 6 & 8.7 & 29 & 8.2 & $0.943(0.376-2.365)$ & 0.900 \\
\hline $\begin{array}{l}\text { Chemical } \\
\text { products* }\end{array}$ & 18 & 4.3 & 7 & 10.1 & 11 & 3.1 & $0.286(0.107-0.765)$ & $0.013^{*}$ \\
\hline Foods & 4 & 1.0 & 3 & 4.3 & 1 & 0.3 & $0.063(0.006-0.612)$ & $0.017^{*}$ \\
\hline
\end{tabular}

*Alcohol with arnica; caustic soda; thinner; sanitary water; bar soap; insecticide; detergent; kerosene; resin; colossus; acetone; muriatic acid; cooking gas. N/A: Not applicable; OR: odds ratio; Cl: Confidence Interval. 
In this study, benzodiazepines and antidepressants were the pharmacological classes responsible for the highest number of intoxications caused by the group of drugs.

Regarding the association between the different therapeutic/pharmacological groups found during the review of medical records and the type of intoxication caused, patients whose toxic agents were non-steroidal anti-inflammatories are less likely to have intentional intoxication (Table 4).

Table 4. Univariate analysis of the association between type of intoxication and main therapeutic/pharmacological groups, of patients attended at the Emergency Care Unit (UPA 24h), Divinópolis-MG, Brazil (2017-2018) ( $n$ = 322).

\begin{tabular}{|c|c|c|c|c|c|c|c|c|}
\hline \multirow[t]{2}{*}{ VARIABLES } & \multicolumn{2}{|c|}{ TOTAL } & \multicolumn{2}{|c|}{$\begin{array}{l}\text { UNINTENTIONAL } \\
\text { INTOXICATION } \\
\end{array}$} & \multicolumn{2}{|c|}{$\begin{array}{l}\text { INTENTIONAL } \\
\text { INTOXICATION } \\
\end{array}$} & \multirow[t]{2}{*}{ OR $(95 \% \mathrm{Cl})$} & \multirow[t]{2}{*}{ p-value } \\
\hline & $\mathbf{N}$ & $\%$ & $\mathbf{N}$ & $\%$ & $\mathbf{N}$ & $\%$ & & \\
\hline Anxiolytics (N05B) & 153 & 47.5 & 5 & 41.7 & 148 & 47.7 & $1.279(0.397-4.117)$ & 0.680 \\
\hline $\begin{array}{l}\text { Anti-depressives } \\
\text { (N06A) }\end{array}$ & 87 & 27.0 & 3 & 25.0 & 84 & 27.1 & $1.115(0.295-4.218)$ & 0.873 \\
\hline $\begin{array}{l}\text { Anti-psychotics } \\
\text { (N05A) }\end{array}$ & 47 & 14.6 & 2 & 16.7 & 45 & 14.5 & $0.849(0.180-4.003)$ & 0.836 \\
\hline Anticonvulsants (N03) & 39 & 12.1 & 2 & 16.7 & 37 & 11.9 & $0.678(0.143-3.214)$ & 0.624 \\
\hline Analgesics (N02B) & 32 & 9.9 & 1 & 8.3 & 31 & 10.0 & $1.222(0.153-9.788)$ & 0.850 \\
\hline $\begin{array}{l}\text { Antihypertensives } \\
\text { (C02) }\end{array}$ & 26 & 8.1 & 1 & 8.3 & 25 & 8.1 & $0.965(0.120-7.782)$ & 0.973 \\
\hline $\begin{array}{c}\text { Non-steroidal anti- } \\
\text { inflammatories (A07) }\end{array}$ & 20 & 6.2 & 3 & 25.0 & 17 & 5.5 & $0.174(0.043-0.702)$ & $0.014 *$ \\
\hline $\begin{array}{c}\text { Synthetic } \\
\text { antispasmodics and } \\
\text { anticholinergics }\end{array}$ & 15 & 4.7 & 0 & 0.0 & 15 & 4.8 & $\mathrm{~N} / \mathrm{A}$ & 0.999 \\
\hline Antihistamines (R06) & 13 & 4.0 & 1 & 8.3 & 12 & 3.9 & $0.443(0.053-3.716)$ & 0.453 \\
\hline Antimicrobials (J01) & 13 & 4.0 & 0 & 0.0 & 13 & 4.2 & $\mathrm{~N} / \mathrm{A}$ & 0.999 \\
\hline $\begin{array}{c}\text { Hypnotics and } \\
\text { Sedatives (N05C) }\end{array}$ & 8 & 2.5 & 0 & 0.0 & 8 & 2.6 & N/A & 0.999 \\
\hline $\begin{array}{c}\text { Natural sedatives } \\
\text { (NO7X) }\end{array}$ & 7 & 2.2 & 0 & 0.0 & 7 & 2.3 & N/A & 0.999 \\
\hline $\begin{array}{l}\text { Anti-obesity agents } \\
\text { (A08) }\end{array}$ & 5 & 1.6 & 0 & 0.0 & 5 & 1.6 & $N / A$ & 0.999 \\
\hline Antiemetics (A04) & 5 & 1.6 & 0 & 0.0 & 5 & 1.6 & $\mathrm{~N} / \mathrm{A}$ & 0.999 \\
\hline Hypolipidemics (C10) & 4 & 1.2 & 0 & 0.0 & 4 & 1.3 & $\mathrm{~N} / \mathrm{A}$ & 0.999 \\
\hline Antidiabetics (A10) & 3 & 0.9 & 0 & 0.0 & 3 & 1.0 & $\mathrm{~N} / \mathrm{A}$ & 0.999 \\
\hline Various (V) & 33 & 10.2 & 1 & 8.3 & 32 & 10.3 & $1.266(0.158-10.131)$ & 0.824 \\
\hline
\end{tabular}

NOTE: The main group is represented by a letter and corresponds to the anatomical group; the first subgroup is represented by two numbers and corresponds to the therapeutic group; the second subgroup is represented by a letter and corresponds to the pharmacological group; the third subgroup is represented by a letter and corresponds to the chemical group. N/A: Not applicable; OR: odds ratio; Cl: Confidence Interval.

When considering the decontamination procedures performed in the initial approach to the intoxicated patient, a predominance in the use of activated charcoal $(53.4 \% ; n=225)$ and gastric lavage $(52.0 \% ; n=219)$ was observed.

Regarding the use of antagonists, the use of flumazenil in $0.2 \%(n=1)$ of cases of benzodiazepine intoxication was identified. In the treatment of accidents by venomous animals, anti-venom serum $(1.4 \% ; n=6)$ and anti-histamines $(3.3 \% ; n=14)$ were used.

\section{DISCUSSION}

This study on intoxications in the city of Divinópolis - MG is important for the knowledge of the profile of patients treated by UPA $24 \mathrm{~h}$, since there is no recent data on this in the city, and such information is relevant for the improvement in resolution of these cases in the municipality. 
It was observed that the most frequent circumstance was suicide attempt. In other studies conducted in Brazil, similar results are found, as in the study by Mathias et al. (2019), where suicide was the main circumstance found in intoxication by drugs in the city of Londrina-PR, with $53.1 \%$ of cases. Likewise, in the case of intoxications caused by anticholinesterase pesticides in Recife-PE, it was noted that $79.4 \%$ of the cases were suicide attempts (Medeiros et al., 2014).

In the present study, benzodiazepines proved to be the main responsible for drug intoxications and secondly, antidepressants. Lim \& Lee (2018) have shown that drugs such as benzodiazepines have predominantly been used in the adult population for suicide attempts. According to Miranda-Mendizabal et al. (2019), one of the factors that increases suicide attempts in both genders is psychiatric illness. Lofman et al. (2017) demonstrated in their study that suicide victims were diagnosed with depression, bipolar disorder, and affective disorders. Thus, it can be inferred that the drugs most used in suicide attempts presented in this study are possibly related to patients with a psychiatric diagnosis.

The number of suicide attempts was higher in females than in males, and some studies have shown that this difference is caused by factors such as greater exposure to psychological abuse, domestic violence, history of abortion, and greater exposure to childhood sexual abuse (Veloso et al., 2017; Miranda-Mendizabal et al., 2019). However in a global aspect, the prevalence of suicides in men is higher than in women (World Health Organization, 2019b).

A high prevalence of intentional toxicological events in the 21 to 30 age group was also observed, as described by Oliveira \& Suchara (2014), and Santana et al. (2019), this prevalence being quite expressive in their studies, and several factors are related to the increase of these events within this age group. According to the authors, intentional toxicological events in individuals of reproductive age are related not only to untreated depressive disorders, but also to easy access to drugs and to the common practice of self-drugs of these individuals, due to the need to resolve the problems of health to maintain the quality of work, personal problems such as difficulty in entering the labor market, and financial problems. This finding is important for risk assessment in suicide prevention.

Another important finding in this study concerns the residential area, as described by Araújo et al. (2019), and Santana et al. (2019) whereby the highest prevalence of the number of suicides occurs in individuals living in the urban area, and may be related to lifestyle and the ease of purchasing medication in the market.

Suicide prevention is one of the priorities of the Ministry of Health (Ministério da Saúde - MS) and represents a challenge for public health as it is a complex, multifaceted and multiple determinant phenomenon. Brazil has made great progress with the launch of Ordinance No. 1.876 of August 14, 2006, instituting the National Guidelines for Suicide Prevention, implemented in all federative units, respecting the competences of the three management spheres (Brasil, 2006).

From this ordinance, other actions were launched by the MS, such as Ordinance No. 3088/2011, establishing the Psychosocial Care Network (Rede de Atenção Psicossocial - RAPS) for people with suffering or mental disorder (Brasil, 2018), and Ordinance No. 3.491/2017 that instituted incentive financial support for the development of health promotion, surveillance and comprehensive health care projects aimed at preventing suicide within the scope of the Psychosocial Care Network of the Unified Health System (Sistema Único de Saúde - SUS) (Brasil, 2017a), among others, however the problem persists. In other countries, suicide was also found as the main circumstance, as reported by Zhang et al. (2018) in China (56.7\%), and Iran with $81.5 \%$ of cases of intoxication (Titidezh et al., 2019).

Among unintentional intoxication, the main exposure circumstance was environmental exposure. The environment is composed of chemical substances, many of which are poisonous if present in large amounts, and some of which are poisonous even in small quantities. Within the industrialized world, specific concentrations of highly dangerous chemicals may be localized to a certain area, vastly increasing the risk to the local environment (Langford \& Ferner, 2002). Muñoz-Quezada et al. (2016), describes that long-term 
environmental exposure to environmental chemicals has been associated with a wide range of acute and chronic health effects. In addition, the exposed population represents an important cause of morbidity.

Considering unintentional intoxication, in research carried out in other countries, it is noticed that the ingestion of drugs is the main cause of accidental intoxication in children, as in Saudi Arabia where $70 \%$ of the exogenous intoxications were caused by drugs (Alghadeer et al., 2018) and in Taiwan 41.4\% corresponded to drug intoxications (Lee et al., 2019). Drug intoxications that occurred in children have multifactorial causes and are generally related to specific conditions of each culture and region (Alghadeer et al., 2018). In relation to the age group of children up to 10 years, patterns similar to the results of our study of accidental intoxication were found in other Brazilian cities. In Londrina, drugs were the main causes of accidental intoxication in children (34.6\%), followed by venomous animals (22.7\%), whereas rodenticides had a lower cause with 5.5\% (Rocha et al., 2019).

In Brazil, one of the factors that may be associated with accidental intoxication in children is the socioeconomic condition, as demonstrated in a study carried out by Margonato et al. (2008), where most of the intoxication notifications correspond to the class $C$ and $D$ population, since they have less access to information. The main agents causing intoxication were drugs. In countries such as Germany (Sorge et al., 2015) and Iran (Mehrpour et al., 2018) this pattern was also observed; in India a different pattern was found, where the main causative agent was organophosphates, and secondly, prescription drugs (Bhowmick et al., 2019).

Regarding the procedure for the treatment of intoxications, it was noticed that the most popular choice was gastric lavage with activated charcoal in cases of oral intoxication. There are already several experimental and clinical types of evidence that confirm that the use of gastric lavage after an hour of intoxication is not advisable (Vale \& Kulig, 2004; Leidenz et al., 2012; Velasco et al., 2014), since there is no evidence that the condition improves, in addition to having risks such as aspiration pneumonia, laryngospasm, arrhythmia, esophageal or stomach perforation, fluid and electrolyte imbalance, and small conjunctival hemorrhages (Benson et al., 2013).

Likewise, the use of activated charcoal must be made within one hour, provided that the toxic substances do not have acidic or alkali characteristics, nor do they have the presence of ethylene, ethanol, glycol, iron, lithium and methanol. However, even following such indications, there is no evidence that its use improves the clinical picture (Vale, 2016). In the present study, the use of atropine, a muscarinic antagonist used in cases of organophosphate intoxication (Braitberg, 2019), was not observed.

Other treatments were used but had a low frequency, which is the case of flumazenil, a benzodiazepine antagonist used in cases of benzodiazepine intoxication (Chern et al., 1998), in which only one of the patients with benzodiazepine intoxication use this treatment. This result can be justified by the fact that flumazenil has adverse effects such as cardiac arrhythmias and seizures, reducing its benefits when used, as demonstrated in a study by Penninga et al. (2016).

In this study, the use of alkalinization as a procedure for the elimination of toxic agents was not identified. Clinical studies in volunteers recommend the use of urinary alkalinization, as the first line of treatment for only two situations: patients with moderate or severe salicylate intoxication who do not meet the criteria for hemodialysis; and patients with intoxication by the 2,4 dichlorophenoxyacetic acid herbicide (2,4 D) (Cohen et al., 2013; Proudfoot et al., 2004).

It is a fact that the municipality is unaware of the real statistics of intoxications in its population. There is no official data recorded in the municipal health system on this health condition. In this sense, the results of this study will serve as a starting point for the knowledge of the high rate of intoxication for suicide attempts in the municipality, especially in the younger age groups (21 to 30 years), in order to guide decision making of municipal public managers in the direction of guidelines for preventive and curative approaches in cases where the intoxication is already effective, whether in the format of training of health professionals, awareness campaigns, or municipal public policies focused on this theme. 


\section{CONCLUSION}

Intoxication has as its main circumstance, suicide attempts by drugs, in women, and in the urban area. Therefore, this research demonstrates that knowledge about the profile of intoxications at the local level may contribute to the development of guidelines for the initial approach, diagnosis, and treatment of intoxications according to the characteristics of these diseases in the municipality of Divinópolis.

Knowing the profile of intoxications in a given population, it is possible to identify potential risk conditions to which individuals are exposed and, thus, prioritize strategies for handling and resolving cases. In addition to being a relevant public health issue, it is also important to raise awareness among health professionals, from other sectors and the general population, with a view to preventing it.

\section{ACKNOWLEDGMENT}

We are grateful to the Federal University of São João del-Rei, Centro-Oeste Dona Lindu Campus (UFSJ-CCO) and to the Emergency Care Unit (UPA 24h) in the municipality of Divinópolis, Minas Gerais, for supporting this work. We also appreciate the support of the Coordination for the Improvement of Higher Education Personnel - Brazil (Coordenação de Aperfeiçoamento de Pessoal de Nível Superior - Brasil - CAPES) - Financing Code 001.

\section{REFERENCES}

Alghadeer S, Alrohaimi M, Althiban A, Kalagi NA, Balkhi B, Khan AA. The patterns of children poisoning cases in community teaching hospital in Riyadh, Saudi Arabia. Saudi Pharm J. 2018;26(1):93-7. http://dx.doi.org/10.1016/j.jsps.2017.10.007. PMid:29379339.

Araújo LS, Alves JMF, Barros KBNT. Intoxicação por medicamentos nas regiões Nordeste e Sudeste: Estudo comparativo no período de 2013 a 2016. Mostra Científica da Farmácia. 2019;5.

Bachmann S. Epidemiology of suicide and the psychiatric perspective. Int J Environ Res Public Health. 2018;15(7):1425. http://dx.doi.org/10.3390/ijerph15071425. PMid:29986446.

Benson BE, Hoppu K, Troutman WG, Bedry R, Erdman A, Hojer J, Mégarbane B, Thanacoody R, Caravati EM. Position paper update: gastric lavage for gastrointestinal decontamination. Clin Toxicol. 2013;51(3):140-6. http://dx.doi.org/10.3109/15563650.2013.770154. PMid:23418938.

Bhowmick K, Ghosh BM, Pain SMBBS. A study on deliberately self-poisoned in-hospital patients in a tertiary health care center in northeast India: a cross-sectional review. J Emerg Med. 2019;56(5):512-8. http://dx.doi.org/10.1016/j.jemermed.2018.10.037. PMid:30879855.

Braitberg G. Acute intoxication and poisoning: drugs and antidotes in acute intoxication. In: Ronco C, Kellum JA, Bellomo R, Ricci Z, editors. Critical care nephrology. 3rd ed. Philadelphia: Elsevier; 2019. p. 574-88. http://dx.doi.org/10.1016/B978-0-323-44942-7.00098-4.

Brasil. Ministério da Saúde. Portaria $n^{\circ}$ 1.876, de 14 de agosto de 2006. Institui Diretrizes Nacionais para Prevenção do Suicídio, a ser implantadas em todas as unidades federadas, respeitadas as competências das três esferas de gestão. Diário Oficial da União; Brasília; 15 ago. 2006.

Brasil. Ministério da Saúde. Portaria n³.491, de 18 de dezembro de 2017. Institui incentivo financeiro de custeio para desenvolvimento de projetos de promoção da saúde, vigilância e atenção integral à saúde direcionados para prevenção do suicídio no âmbito da Rede de Atenção Psicossocial do Sistema Único de Saúde (SUS), a onerarem o orçamento de 2017. Diário Oficial da União; Brasília; 22 dez. 2017a.

Brasil. Sistema de Informação de Agravos de Notificação - SINAN. Estatística anual de casos de notificações segundo o agente tóxico [Internet]. Brasília (DF); 2017b [cited 2020 Apr 23]. Available from: http://www.portalsinan.saude.gov.br/o-sinan

Brasil. Ministério da Saúde. Secretaria de Vigilância em Saúde. Departamento de Vigilância em Saúde Ambiental e Saúde do Trabalhador. Instruções para preenchimento da Ficha de Investigação de Intoxicação Exógena SINAN - Sistema de Informação de Agravos de Notificação. Brasília (DF): Ministério da Saúde; 2018. 
Chaves LHS, Viana AC, Mendes WP Jr, Silva AL, Serra LC. Intoxicação exógena por medicamentos: aspectos epidemiológicos dos casos notificados entre 2011 e 2015 no Maranhão. Reon Facema. 2017;3(2):477-82.

Chen L, Zeng WM, Cai YD, Feng KY, Chou KC. Predicting Anatomical Therapeutic Chemical (ATC) classification of drugs by integrating chemical-chemical interactions and similarities. PLoS One. 2012;7(4):e35254. http://dx.doi.org/10.1371/journal.pone.0035254. PMid:22514724.

Chern CH, Chern TL, Wang LM, Hu SC, Deng JF, Lee CH. Continuous flumazenil infusion in preventing complications arising from severe benzodiazepine intoxication. Am J Emerg Med. 1998;16(3):23841. http://dx.doi.org/10.1016/S0735-6757(98)90091-2. PMid:9596422.

Cohen B, Laish I, Brosh-Nissimov T, Hoffman A, Katz LH, Braunstein R, Sagi R, Michael G. Efficacy of urine alkalinization by oral administration of sodium bicarbonate: a prospective open-label trial. Am J Emerg Med. 2013;31(12):1703-6. http://dx.doi.org/10.1016/j.ajem.2013.08.031. PMid:24055481.

Epifânio IS, Magalhães LMV, Brandespim DF. Casos de intoxicação exógena no estado de Pernambuco no ano de 2017. R Inf Cult. 2019;1(2):27-42. http://dx.doi.org/10.21708/issn26746549.v1i2a8418.2019.

Gummin DD, Mowry JB, Spyker DA, Brooks DE, Beuhler MC, Rivers LJ, Hashem HA, Ryan ML. Annual Report of the American Association of Poison Control Centers' National Poison Data System (NPDS): 36th Annual Report. Clin Toxicol. 2019;57(12):1220-413. http://dx.doi.org/10.1080/15563650.2019.1677022. PMid:31752545.

Instituto Brasileiro de Geografia e Estatística - IBGE. Lista de meso e microrregiões do IBGE [Internet]. Rio de Janeiro; 2010 [cited 2020 Apr 23]. Available from: http://www.ibge.gov.br

Langford NJ, Ferner RE. Episodes of environmental poisoning worldwide. Occup Environ Med. 2002;59(12):855-60. http://dx.doi.org/10.1136/oem.59.12.855. PMid:12468757.

Lee J, Fan NC, Yao TC, Hsia SH, Lee EP, Huang JL, Wu HP. Clinical spectrum of acute poisoning in children admitted to the pediatric emergency department. Pediatr Neonatol. 2019;60(1):59-67. http://dx.doi.org/10.1016/j.pedneo.2018.04.001. PMid:29748113.

Leidenz FAB, Júnior WFF, Lucciola GR. Lavagem gástrica realmente efetiva? Rev Med Minas Gerais. 2012;22(Supl 8):S1-48.

Lim JY, Lee DH. Characteristics of drugs ingested for suicide attempts in the elderly. J Korean Med Sci. 2018;33(11):e86.

Löfman S, Hakko H, Mainio A, Riipinen P. Affective disorders and completed suicide by selfpoisoning, trend of using antidepressants as a method of self-poisoning. Psychiatry Res. 2017;255:360-6. http://dx.doi.org/10.1016/j.psychres.2017.05.031. PMid:28628870.

Margonato FB, Thomson Z, Paoliello MMB. Determinantes nas intoxicações medicamentosas agudas na zona urbana de um município do Sul do Brasil. Cad Saude Publica. 2008;24(2):333-41. http://dx.doi.org/10.1590/S0102-311X2008000200012. PMid:18278280.

Mathias TL, Guidoni CM, Girotto E. Tendências de eventos toxicológicos relacionados a medicamentos atendidos por um Centro de Informações Toxicológicas. Rev Bras Epidemiol. 2019;22:e190018. http://dx.doi.org/10.1590/1980-549720190018.

Medeiros MNC, Medeiros MC, Silva MBA. Intoxicação aguda por agrotóxicos anticolinesterásicos na cidade do Recife - Pernambuco. 2007-2010. Epidemiol Serv Saude. 2014;23(3):509-18. http://dx.doi.org/10.5123/S1679-49742014000300013.

Mehrpour O, Akbari A, Jahani F, Amirabadizadeh A, Allahyari E, Mansouri B, Ng PC. Epidemiological and clinical profiles of acute poisoning in patients admitted to the intensive care unit in eastern Iran (2010 to 2017). BMC Emerg Med. 2018;18(1):30. http://dx.doi.org/10.1186/s12873-018-0181-6. PMid:30231863.

Miranda-Mendizabal A, Castellví P, Parés-Badell O, Alayo I, Almenara J, Alonso I, Blasco MJ, Cebrià A, Gabilondo A, Gili M, Lagares C, Piqueras JA, Rodríguez-Jiménez T, Rodríguez-Marín J, Roca M, SotoSanz V, Vilagut G, Alonso J. Gender differences in suicidal behavior in adolescents and young adults: systematic review and meta-analysis of longitudinal studies. Int J Public Health. 2019;64(2):265-83. http://dx.doi.org/10.1007/s00038-018-1196-1. PMid:30635683.

Muñoz-Quezada MT, Lucero BA, Iglesias VP, Muñoz MP, Cornejo CA, Achu E, Baumert B, Hanchey A, Concha C, Brito AM, Villalobos M. Chronic exposure to organophosphate (OP) pesticides and neuropsychological functioning in farm workers: a review. Int J Occup Environ Health. 2016;22(1):68-79. http://dx.doi.org/10.1080/10773525.2015.1123848. PMid:27128815. 
Oliveira DH, Suchara EA. Intoxicações medicamentosas em hospital público de Barra do Garças -MT, no período de 2006 a 2009. Rev Ciênc Méd Biol. 2014;13(1):55-9. http://dx.doi.org/10.9771/cmbio.v13i1.10117.

Penninga El, Graudal N, Ladekarl MB, Jurgens G. Adverse events associated with flumazenil treatment for the management of suspected benzodiazepine intoxication: a systematic review with metaanalyses of randomised trials. Basic Clin Pharmacol Toxicol. 2016;118(1):37-44. http://dx.doi.org/10.1111/bcpt.12434. PMid:26096314.

Proudfoot AT, Krenzelok EP, Vale JA. Position paper on urine alkalinization. J Toxicol. 2004;42(1):1-26. PMid:15083932.

Ribeiro NM, Castro SS, Scatena LM, Haas VJ. Análise da tendência temporal do suicídio e de sistemas de informações em saúde em relação às tentativas de suicídio. Texto Contexto Enferm. 2018;27(2):111. http://dx.doi.org/10.1590/0104-070720180002110016.

Rocha EJS, Gonzalez AD, Girotto E, Guidoni CM. Análise do perfil e da tendência dos eventos toxicológicos ocorridos em crianças atendidas por um Hospital Universitário. Cad Saude Colet. 2019;27(1):53-9. http://dx.doi.org/10.1590/1414-462x201900010333.

Santana VTP, Suchara EA, Carreto R, Duarte P. Perfil das Intoxicações Medicamentosas Notificadas ao SINAN no Município de Primavera do Leste - MT, Entre os Anos de 2007 a 2014. Ensen Cienc. 2019;23(3):230-7. http://dx.doi.org/10.17921/1415-6938.2019v23n3p230-237.

Sorge M, Weidhase L, Bernhard M, Gries A, Petros S. Self-poisoning in the acute care medicine 2005-2012. Anaesthesist. 2015;64(6):456-62. http://dx.doi.org/10.1007/s00101-015-0030-x. PMid:25951922.

Titidezh V, Arefi M, Taghaddosinejad F, Behnoush B, Akbar Pour S, Mahboobi M. Epidemiologic profile of deaths due to drug and chemical poisoning in patients referred to Baharloo Hospital of Tehran, 2011 to 2014. J Forensic Leg Med. 2019;64:31-3. http://dx.doi.org/10.1016/j.jflm.2019.02.009. PMid:30927562.

Vale A. Reducing absorption and increasing elimination. Management. 2016;44(2):99-100.

Vale JA, Kulig K. American Academy of Clinical Toxicology, European Association of Poisons Centres and Clinical Toxicologists. Position statement: gastric lavage. J Toxicol. 2004;42:933-43.

Velasco R, Palacios M, Salmón N, Acedo Y, Del Arco L, Azcunaga B, Mintegi S. Impact of a working group on gastrointestinal decontamination in Spanish emergency departments. Eur J Emerg Med. 2014;21(3):195-8. http://dx.doi.org/10.1097/MEJ.0b013e3283610f0b. PMid:23542421.

Veloso C, Monteiro CFS, Veloso LVP, Figueiredo MLF, Fonseca RSB, Araujo RSB, Machado RDS. Violência autoinfligida por intoxicação exógena em um serviço de urgência e emergência. Rev Gaúcha Enferm. 2017;38(2):e66187. http://dx.doi.org/10.1590/1983-1447.2017.02.66187. PMid:28700026.

World Health Organization. Pan American Health Organization. International Programme on Chemical Safety. The public health impact of chemicals: knowns and unknowns. Geneva: WHO; 2018. 13 p.

World Health Organization. International Programme on Chemical Safety: poisoning prevention and management [Internet]. Geneva: WHO; 2019a [cited 2020 Mar 25]. Available from: http://https://www.who.int/ipcs/poisons/en/

World Health Organization. Suicide in the world: global health estimates [Internet]. Geneva: WHO; 2019b [cited 2020 Aug 25]. Available from: https://apps.who.int/iris/bitstream/handle/10665/326948/WHO-MSD-MER-19.3eng.pdf?sequence=1\&isAllowed=y

Zhang Y, Yo B, Wang N, Li T. Acute poisoning in Shenyang, China: a retrospective and descriptive study from 2012 to 2016. BMJ Open. 2018;8:1-11.

\section{Authors' contributions: ACATDP ${ }^{1-3}, \mathrm{TLSS}^{1-3}, \mathrm{GCSA}^{2-3}, \mathrm{SMLF}^{2-3}, \mathrm{AO}^{1-3}, \mathrm{CS}^{1-3}, \mathrm{FMDC}^{1-3}$}

1- Conceived, planned and carried out the data collect presented in the manuscript or interpreted the data, or both.

2- Wrote the paper, or reviewed successive versions.

3- Approved the final version 